\title{
Application of the differential display RT-PCR strategy for the identification of inflammation-related mouse genes
}

\section{A.M. Silva ${ }^{1,2}$, E.G. Pires ${ }^{1}$, E.F. Abrantes ${ }^{1,3}$, L.R.P. Ferreira ${ }^{3}$, R.T. Gazzinelli ${ }^{3}$ and L.F.L. Reis ${ }^{1}$}

\author{
${ }^{1}$ Laboratório de Inflamação, Instituto Ludwig de Pesquisa sobre o Câncer, \\ São Paulo, SP, Brasil \\ Departamentos de ${ }^{2} \mathrm{M}$ icrobiologia and ${ }^{3}$ Bioquímica e Imunologia, \\ Instituto de Ciências Biológicas, Universidade Federal de Minas Gerais, \\ Belo Horizonte, MG, Brasil
}

\section{Correspondence \\ L.F.L. Reis \\ Laboratório de Inflamação \\ Instituto Ludwig de Pesquisa sobre o Câncer \\ Rua Prof. Antônio Prudente, 109 \\ 01509-010 São Paulo, SP \\ Brasil \\ Fax: + 55-11-270-7001 \\ E-mail: Ireis@ node1.com.br \\ Presented at the I International Symposium on "Signal Transduction and Gene Expression in Cell Proliferation and Differentiation", São Paulo, SP, Brasil, \\ August 31-September 2, 1998.}

Research supported by PADCT, FAPESP, CAPES, and CNPq.

Received November 26, 1998 Accepted January 26, 1999

\section{Abstract}

The inflammatory response elicited by various stimuli such as microbial products or cytokines is determined by differences in the pattern of cellular gene expression. We have used the differential display RTPCR (DDRT-PCR) strategy to identify mRNAs that are differentially expressed in various murine cell types stimulated with pro-inflammatory cytokines, microbial products or anti-inflammatory drugs. Mouse embryonic fibroblasts (MEFs) were treated with IFNs, TNF, or sodium salicylate. Also, peritoneal macrophages from $\mathrm{C} 3 \mathrm{H} / \mathrm{Hej}$ mice were stimulated with T. cruzi-derived GPI-mucin and/or IFN- $\gamma$. After DDRTPCR, various cDNA fragments that were differentially represented on the sequencing gel were recovered, cloned and sequenced. Here, we describe a summary of several experiments and show that, when 16 of a total of 28 recovered fragments were tested for differential expression, $5(31 \%)$ were found to represent mRNAs whose steady-state levels are indeed modulated by the original stimuli. Some of the identified cDNAs encode for known proteins that were not previously associated with the inflammatory process triggered by the original stimuli. Other cDNA fragments ( 8 of 21 sequences, or $38 \%$ ) showed no significant homology with known sequences and represent new mouse genes whose characterization might contribute to our understanding of inflammation. In conclusion, DDRT-PCR has proven to be a potent technology that will allow us to identify genes that are differentially expressed when cells are subjected to changes in culture conditions or isolated from different organs.

\section{Introduction}

The identification of genes that are differentially expressed in cells exposed to microbial products, pro-inflammatory cytokines, or anti-inflammatory drugs can help us understand the molecular basis of the inflammatory response and may point out potential
Key words

- DDRT-PCR

- Gene expression

- Inflammation

- TNF

- Interferon new targets for drug therapy. We have used the inflammatory response as a model to evaluate the differential display RT-PCR (DDRT-PCR) (1) as a tool to compare the mRNA content of cells exposed to different stimuli that mimic a stage of the inflammatory response. Current methods for comparing the gene expression profile of different 
cell types or of cells that are kept under different conditions include, among others, the DDRT-PCR $(1,2)$, RAP-PCR (3), subtractive cDNA libraries obtained by differential screening (4), SAGE (5), RDA-analysis (6), and more recently cDNA microarray analysis $(7,8)$. A review of the literature shows that all of these procedures have intrinsic advantages and disadvantages that have to be balanced before a method is chosen $(9,10)$. Normally, a gain of sensitivity will imply an increased background of fragments that do not represent a bona fide differentially expressed gene. Here, we show that, after detailed optimization, the DDRTPCR is a simple, fast, and reliable technique that can identify a high percentage of genes whose pattern of expression can be predicted based upon the pattern of the corresponding fragment.

A variety of pro-inflammatory cytokines like interferons (IFNs), interleukins (ILs), or tumor necrosis factor (TNF) are pleiotropic cytokines that play an important role as antiviral agents, as immune modulators, and in the regulation of cell growth and differentiation (11). In order to exert their biological activities, these cytokines bind to specific cell-surface receptors, leading to the activation or inactivation of the expression of a large set of genes (11).

Interferons bind to two distinct cellular receptors, one specific for the type I IFN family (comprising IFN- $\alpha,-\beta$, and $-\omega$ ) and one specific for the type II IFN or IFN- $\gamma$. Binding of IFNs to their specific receptors will trigger a signaling cascade that is mediated primarily by the activation of tyrosine kinases of the Janus family (JAKs). Activated JAKs will in turn phosphorylate the members of STAT (for signal transducers and activators of transcription) family of proteins that will activate the expression of the so-called IFN-stimulated genes (ISGs). Another transcription factor, interferon regulatory factor-1 (IRF-1), has also been implicated as an important transcription factor for the activation of ISGs. Interferon signaling has been extensively reviewed in recent publications (12-18). The proteins encoded by the different ISGs will mediate most of the biological activities of interferons. Examples of functionally characterized ISGs are the family of 2'5-OAS (19), the dsRNA-dependent serine-threonine kinase PKR $(20,21)$, and the MX protein (22) necessary for resistance to influenza virus. Even though an evergrowing number of ISGs are now being identified, the exact mechanism of action of IFNs remains obscure, with the need to identify new genes that would help us to clarify the cytokine network.

Like IFNs, the actions of TNF are also mediated by several proteins encoded by genes expressed upon binding of TNF to its cellular receptors. In the case of TNF, induction of gene expression is achieved by the activation of the transcription factor NF- $\mathrm{kB}$ that exists as a latent form in the cytoplasm, bound to the inhibitory component IкB. Phosphorylation of I $\mathrm{I} B$ leads to its dissociation from NF- $\kappa \mathrm{B}$ and subsequent degradation, with migration of active NF- $\kappa B$ to the nucleus (23-25). Interestingly, recent evidence has indicated that the treatment of cells with the non-steroid anti-inflammatory compound sodium salicylate leads to inhibition of IкB phosphorylation and degradation, suggesting that blocking of TNF signaling might be an effective approach for anti-inflammatory therapy (26-28).

During the inflammatory response triggered by infectious agents, immune competent cells are activated and secrete IFNs, TNF, and many other pro-inflammatory cytokines. Thus, it is also relevant to compare the mRNA population in cells of the immune system that are exposed to microbial products. One of the factors responsible for macrophage activation during T. cruzi infection are glycosylphosphatidylinositol anchored mucin-like glycoproteins (GPI-mucins) (29). Exposure of macrophages to $T$. cruzi-derived GPI-mucin activates the expression of 
the genes encoding for IL-12 (29) or nitric oxide synthesis in IFN- $\gamma$-primed macrophages $(30,31)$. Hence, one can speculate that, by comparing the mRNA content of control, untreated macrophages versus GPI-mucintreated macrophages, it might be possible to identify new genes that are activated in response to $T$. cruzi infection.

With the aid of DDRT-PCR, we compared the mRNA content of cells stimulated with various cytokines or microbial products and searched for cDNA fragments that could represent genes that were differentially expressed in response to these treatments. The identification and functional characterization of these genes could identify new aspects of the inflammatory response and, moreover, they could be new targets for drug discovery.

\section{Material and Methods}

\section{Cell culture, exposure of cells and/or mice to different stimuli, and total RNA isolation}

Heterozygous IRF-1 mice (32) were intercrossed and mouse embryonic fibroblasts were prepared from the resulting 12-14-dayold embryos. Individual embryos were transferred to tissue culture dishes containing $10.0 \mathrm{ml}$ PBS and primary fibroblasts were obtained. Mouse embryonic fibroblasts (MEFs) were allowed to grow to near confluence in DMEM containing 10\% FBS. For induction by cytokines, cells were treated with $500 \mathrm{IU} / \mathrm{ml}$ of rhuIFN- $\alpha 2 / \alpha 1$ or $30 \mathrm{ng} /$ $\mathrm{ml}$ of rmuTNF- $\alpha$ (all cytokines from R \& D Systems, Minneapolis, MN, USA). Sodium salicylate was purchased from Sigma and dissolved to $1 \mathrm{M}$ concentration in deionized water. Peritoneal macrophages from $\mathrm{C} 3 \mathrm{H} /$ Hej mice were also cultured in DMEM supplemented with $10 \%$ FCS and stimulated with $T$. cruzi-derived GPI-mucin $(2 \mathrm{pg} / \mathrm{ml})$ and/or IFN- $\gamma(100 \mathrm{IU} / \mathrm{ml})$ for $6 \mathrm{~h}$. Total RNA extraction from cell cultures under different conditions was performed as described (33).
To determine the in vivo expression of ISGs, wild type mice or mice with IRF-1 (32) or STAT-1 (34) deficiency were treated orally with $1 \mathrm{mg} / \mathrm{kg}$ of imiquimod, a potent inducer of IFN synthesis $(35,36)$ (provided by $3 \mathrm{M}$ Pharmaceuticals, St. Paul, MN, USA). After $4 \mathrm{~h}$ of treatment, animals were sacrificed and organs were collected and frozen until total RNA extraction as described (33).

\section{Generation of CDNA fragments by DDRT-PCR}

Two hundred nanograms of DNasetreated total RNA from cell cultures under different conditions were reverse transcribed in a mix containing $20 \mu \mathrm{M}$ dNTPs, $10 \mathrm{mM}$ DTT, 200 U MMLV-reverse transcriptase, and RT-buffer in the presence of $25 \mathrm{pmol}$ of one of the anchored oligo $\mathrm{T}_{11} \mathrm{VN}$ (where $\mathrm{V}$ is A, C or G, and, N can be A, C, G or T) at $42^{\circ} \mathrm{C}$ for $1 \mathrm{~h}$. One tenth of the cDNA first strand reaction was used as template for the DD-PCR reaction in the presence of PCR-buffer $(0.01 \mathrm{M}$ Tris- $\mathrm{HCl}, 0.05 \mathrm{M} \mathrm{KCl}$, $2.5 \mathrm{mM} \mathrm{MgCl}_{2}$ ), $20 \mu \mathrm{M}$ all dNTPs, and $\left[\alpha-{ }^{32} \mathrm{P}\right] \mathrm{dCTP}$, using the same anchored oligo $(2.5 \mu \mathrm{M})$ plus a set of three random 10-mer primers: PR13: 5'-ctgatccatg-3', PR14: 5'ctgctctcaa-3', PR15: 5'-gaactaacgg-3', at a final concentration of $0.5 \mu \mathrm{M}$. The conditions for PCR reaction were as follows: $94^{\circ} \mathrm{C} /$ $4 \mathrm{~min}$ for one cycle, $94^{\circ} \mathrm{C} / 30 \mathrm{~s}, 40^{\circ} \mathrm{C} / 2 \mathrm{~min}$, $72^{\circ} \mathrm{C} / 30 \mathrm{~s}$, for 40 cycles plus a final extension at $72^{\circ} \mathrm{C}$ for $10 \mathrm{~min}$. An aliquot of radioactive products was fractionated on $6 \%$ acrylamide/8 M urea sequencing gel at $1500 \mathrm{~V}$ until xylene-cyanol reached the bottom of the gel. The gel was covered with plastic film $\left(\right.$ SaranWrap ${ }^{\circledR}$ ) and exposed to autoradiogram film.

\section{Sequencing and analysis}

The cDNA fragments were recovered from the sequencing gels, eluted, re-amplified with the same set of primers as used in DDRT-PCR and sub-cloned into a pUC18 
(Pharmacia, Uppsala, Sweden) or pGEM $7 \mathrm{zf}(+)$ vector (Promega, Madison, WI, USA). Plasmids derived from at least two different colonies were sequenced on automated DNA sequencers (A.L.F. Sequencer or ABI Perkin Elmer Cetus). Sequence homology of the cloned cDNA fragments with known cDNAs was determined using the BLAST program (37).

\section{Northern and Southern blot analysis, and RT-PCR assessment}

For Northern blot analysis, $15 \mu \mathrm{g}$ of total RNA were fractionated on $1 \%$ denaturing agarose/formaldehyde gel and transferred by capillarity to a Hybond filter (Amersham, Buckinghamshire, UK) as described (38). For Southern blot, $20 \mu \mathrm{g}$ of digested mouse genomic DNA were fractionated on $0.8 \%$ agarose gel as described elsewhere (38). Prehybridization, hybridization and washes were performed as described (39). Filters were probed with $\left[\alpha-{ }^{32} \mathrm{P}\right] \mathrm{dCTP}-$ labeled cDNA fragments at a specific activity of $1 \times 10^{9}$ $\mathrm{cpm} / \mu \mathrm{g}$ for the cDNA probe and exposed to X-ray films. For RT-PCR analysis, $1 \mu \mathrm{g}$ of DNA-free total RNA was reverse transcribed with $0.5 \mu \mathrm{g}$ oligo $\mathrm{dT}_{12-18}, 200 \mu \mathrm{M}$ dNTPs, RT-buffer, 0.01 M DTT, 200 units of SuperScript II (Gibco BRL, Gaithesburg, MD) at $42^{\circ} \mathrm{C}$ for $60 \mathrm{~min}$. One tenth of the first strand reaction was used as template for PCR reactions in the presence of specific primers designed for each cDNA fragment.

\section{Results and Discussion}

In this report, we describe the application of the DDRT-PCR as a tool to identify genes differentially expressed by cells exposed to different stimuli that mimic the inflammatory response. We performed a total of 84 reactions using three different random primers in combination with different anchored primers (see Material and Methods). On av- erage, we observed 40-50 individually expressed bands per lane on the sequencing gel. About 100 bands were recovered from the gels and, so far, 28 have been cloned. On average the length of re-amplified cDNA fragments varies from 100 to 900 bp. In our model, we show that, when optimized, DDRT-PCR can yield a high percentage of cDNA fragments that indeed correspond to mRNAs. Of the 28 cloned and sequenced cDNA fragments, 21 (78\%) correspond to bona fide mRNAs and 5 of 16 sequences $(31 \%)$ tested by Northern blot or RT-PCR were proven to be differentially expressed. Of the 21 fragments that correspond to an mRNA, 8 (38\%) represent newly identified mouse sequences and some of them have no significant homology with other sequences deposited in the GenBank (Table 1).

We have partially characterized 13 expressed cDNA fragments that hybridize with mRNAs in Northern blots, 3 that are amplified by RT-PCR, and 4 that have significant homology with known sequences, mainly ESTs deposited in GenBank. Among the five mRNAs that are differentially expressed, two are new ISGs, one is a new TNF-stimulated gene, one is stimulated by $T$. cruziderived GPI-mucin, and one mRNA is modulated by sodium salicylate.

FRAG-6 is one of the new genes that we have shown to be differentially expressed on IFN-treated cells (Figure 1). The probe of 576 bp strongly hybridizes with two mRNA transcripts of 4 and 7-9 kb, that are upregulated in various organs of imiquimodtreated wild type or IRF-1 ${ }^{0 / 0}$ mice. We have also found that the expression of the FRAG6 gene is abrogated in STAT-1-deficient mice, suggesting that regulation of FRAG- 6 gene expression is regulated by the JAK/ STAT pathway (40).

Since the sensitivity of Northern blot is lower than that of DDRT-PCR, it is often observed that DDRT-PCR-derived probes give no detectable hybridization in Northern 
Table 1 - Generation of expressed CDNA fragments by DDRT-PCR, their sequence similarities having sequences deposited in non-redundant and ESTs Genbank data, and assessment of their expression.

Note that for some cDNA fragments there is no similarity, but their gene expression is confirmed by Northem blot analysis. NaSal: Sodium salicylate; N: Northern blot analysis; S: Southern blot analysis; N/S: both Northern and Southem analyses; nd: not determined.

\begin{tabular}{|c|c|c|c|c|c|c|c|}
\hline & Clones & $\begin{array}{l}\text { Length } \\
\text { (bp) }\end{array}$ & $\begin{array}{l}\text { Sequence homology } \\
\text { from BLAST search }\end{array}$ & $\begin{array}{l}\text { Accession } \\
\text { number }\end{array}$ & $\begin{array}{l}\text { Stimulation } \\
\text { with }\end{array}$ & $\begin{array}{l}\text { Expression } \\
\text { assessed by }\end{array}$ & $\begin{array}{l}\text { Differential } \\
\text { expression }\end{array}$ \\
\hline 1) & 059A14+ & 253 & None & - & TNF & $\mathrm{N}$ & TNF-induced \\
\hline 2) & $13 \mathrm{~A} 10 \mathrm{~b}$ & 361 & None & - & $\mathrm{NaSal} / \mathrm{TNF}$ & nd & - \\
\hline 3) & 13АЗа & 206 & Mouse ribosomal protein S3a & emb/Z83368 & $\mathrm{NaSal} / \mathrm{TNF}$ & $\mathrm{N}$ & Not altered \\
\hline 4) & $13 C 2 R$ & 367 & Human vinculin mRNA & gb/M33308 & NaSal/TNF & $\mathrm{N}$ & Not altered \\
\hline 5) & $13 \mathrm{G} 1$ & 242 & None & - & $\mathrm{NaSal} / \mathrm{TNF}$ & nd & - \\
\hline 6) & $13 \mathrm{~T} 1$ & 357 & Mouse lymph node EST & gb/AA186096 & $\mathrm{NaSal} / \mathrm{TNF}$ & $\mathrm{N}$ & Not altered \\
\hline 7) & 13 T5 & 309 & Rat mevalonate kinase & gb/M29472 & $\mathrm{NaSal} / \mathrm{TNF}$ & $\mathrm{N}$ & Not altered \\
\hline 8) & $13 T 6$ & 311 & Rat mevalonate kinase & gb/M29472 & $\mathrm{NaSal} / \mathrm{TNF}$ & $\mathrm{N}$ & Not altered \\
\hline 9) & $13 \mathrm{~T} 8$ & 262 & Mouse MHC class III & gb/AF030001 & $\mathrm{NaSal} / \mathrm{TNF}$ & RT-PCR & Not altered \\
\hline 10) & 13VC3 & 189 & $\begin{array}{l}\text { Mouse EST similar to protein } \\
\text { carboxyl methyl-transferase }\end{array}$ & gb/AA266007 & NaSal/TNF & nd & - \\
\hline 11) & $15 \mathrm{VC1}$ & 183 & None & - & NaSal/TNF & nd & - \\
\hline 12) & CTR-3 & 223 & Mouse embryo EST & gb/AA030676 & $\mathrm{NaSal} / \mathrm{TNF}$ & RT-PCR & NaSal-inhibited \\
\hline 13) & FRAG-1 & 845 & Mouse type $V$ alpha- 2 collagen & gb/L02918 & IFN & $\mathrm{N}$ & Not altered \\
\hline 14) & FRAG-3 & 509 & None & - & IFN & $\mathrm{S}$ & - \\
\hline 15) & FRAG-6 & 576 & None & - & IFN & N/S & IFN-induced \\
\hline 16) & GPI-3 & 200 & Mouse $28 \mathrm{~S}$ ribosomal RNA & emb/X00525 & GPI-mucin & $\mathrm{N} / \mathrm{S}$ & Not altered \\
\hline 17) & GPI-7 & 269 & Chinese hamster protein kinase & gb/M63312 & GPI-mucin & RT-PCR & Not altered \\
\hline 18) & GPI-8 & 193 & None & - & GPI-mucin & nd & - \\
\hline 19) & GPI-9 & 105 & Mouse SAA3 mRNA & emb/X03506 & GPI-mucin & $\mathrm{N} / \mathrm{S}$ & GPI-mucin-induced \\
\hline 20) & GPIg-3 & 151 & Human fetal brain EST & gb/U50573 & GPI-mucin & nd & - \\
\hline 21) & $\mathrm{KOI}-3$ & 180 & Human fetal heart EST & gb/W93552 & IFN & nd & - \\
\hline 22) & KOI-4 & 140 & Mouse embryo EST & gb/AA840201 & IFN & $\mathrm{N} / \mathrm{S}$ & IFN-induced \\
\hline 23) & KONI-1 & 158 & None & - & IFN & nd & - \\
\hline 24) & NASA4a & 294 & Rat mevalonate kinase & gb/M29472 & $\mathrm{NaSal} / \mathrm{TNF}$ & nd & - \\
\hline 25) & NASA4b & 167 & Mouse EST & gb/AA169064 & $\mathrm{NaSal} / \mathrm{TNF}$ & nd & - \\
\hline 26) & NASAC-3 & 275 & Mouse GAPDH & gb/M32599 & $\mathrm{NaSal} / \mathrm{TNF}$ & $\mathrm{N}$ & Not altered \\
\hline 27) & SALI-1 & 169 & None & - & NaSal/TNF & nd & - \\
\hline 28) & WTI-2 & 199 & Rat EST from PC-12 cells & gb/AA684985 & IFN & N/S & Not altered \\
\hline
\end{tabular}
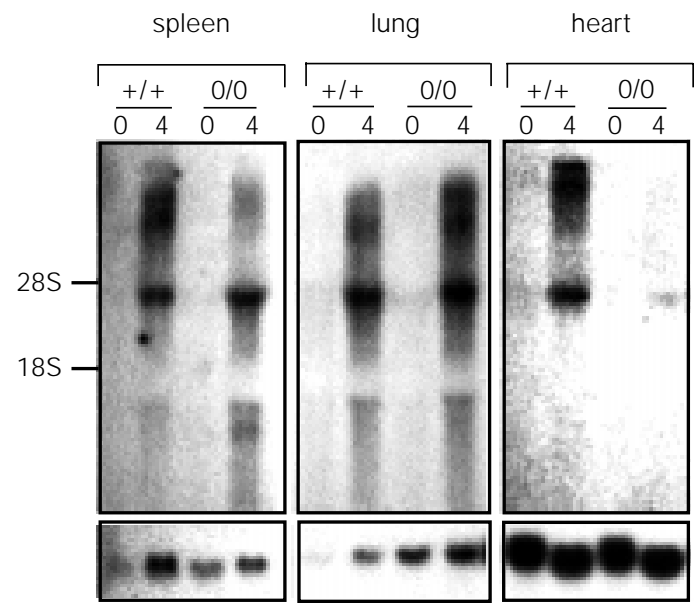

thymus
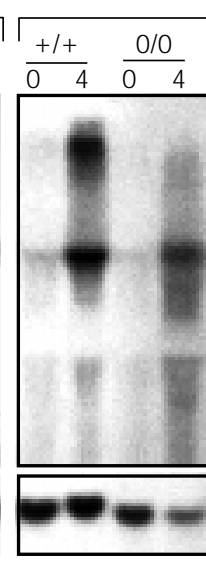

(hours)

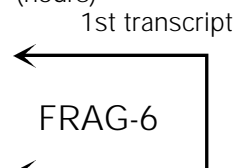

2nd transcript

GAPDH
Figure 1 - In vivo induction of FRAG6 , a new mouse interferon stimulated gene identified by DDRT-PCR. Wild type $(+/+)$ or IRF- $10 / 0(0 / 0)$ mice were treated orally with imiquimod, a potent inducer of interferon synthesis, for $4 \mathrm{~h}$ or left untreated $(0 \mathrm{~h})$. Animals were sacrificed, organs were collected, and total RNA was isolated. Fifteen micrograms of total RNA was fractionated on $0.8 \%$ denaturing-agarose gel, transferred to a nylon membrane, and hybridized with a [ $\alpha-32$ P]dCTP-labeled FRAG- 6 CDNA fragment. In order to ensure equal RNA loading, the filter was stripped and re-hybridized with a $[\alpha-$ $[\alpha-32$ P]dCTP-labeled mouse GAPDH. 


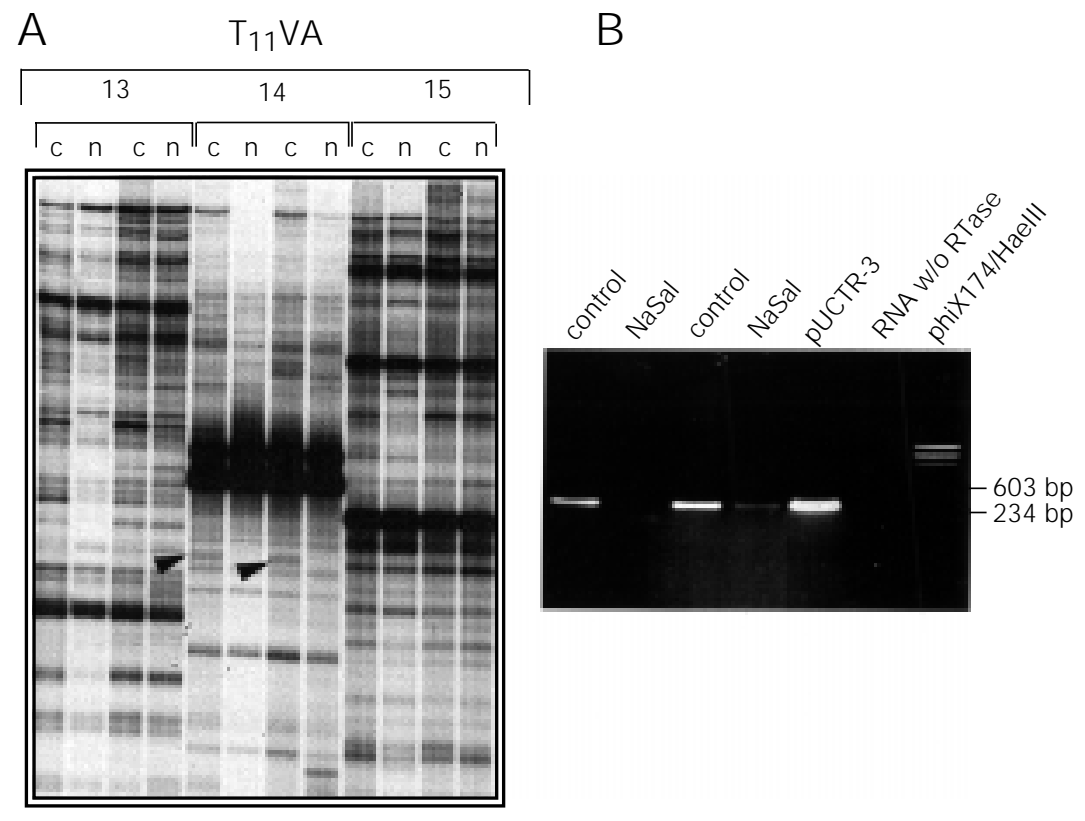

blot analysis. In these cases, we have investigated the expression of the putative differentially expressed mRNA by RT-PCR. In Figure 2A, we show a DDRT-PCR sequencing gel with a differentially represented band (arrowhead). When the cDNA fragment was used as a probe in Northern blot we did not detect any specific hybridization. However, by RT-PCR (Figure 2B), we can see that CTR-3 mRNA is detectable in control, untreated cells but, upon treatment with sodium salicylate, its steady-state level is significantly diminished. We also found that the TNF-induced expression of Cdc2 kinase is inhibited when cells are treated simultaneously with TNF and sodium salicylate (data not shown). We are now using this approach to gain some insight into the molecular mechanism of action of sodium salicylate as an anti-inflammatory drug (Silva AM and Reis LFL, unpublished data). It will be interesting to compare the promoter regions of the $\mathrm{Cdc} 2$ kinase and CTR-3 genes to determine the molecular bases of transcription inhibition by sodium salicylate. Finally, a new TNF-
Figure 2 - DDRT-PCR analysis and identification of a sodium salicylate (NaSal)-inhibited gene. A, Total RNA was extracted from near confluent control untreated cells (c) or after $4 \mathrm{~h}$ of stimulation with sodium salicylate $(20 \mathrm{mM})(\mathrm{n})$. The cDNA first strand was obtained from DNase-treated total RNA with the anchored oligo $\mathrm{T}_{11} \mathrm{VA}$ in the presence of dNTPs and MMLV-reverse transcriptase. One tenth of the first strand reaction was amplified by PCR using a combination of different random primers in the presence of $[\alpha-32 \mathrm{P}] \mathrm{dCTP}$ and dNTP mix. The products were analyzed on a $6 \%$ sequencing gel. Duplicate samples from control (c) or sodium salicylate-treated $(n)$ cells were obtained from independent CDNA first strand and PCR reactions. Arrowheads indicate a putative differentially expressed band named CTR-3. B, Assessment of the differential expression of CTR-3 by RT-PCR. After recovering from the sequencing gel, elution, re-amplification, cloning and sequencing, specific primers were designed for the CTR-3 cDNA fragment. The two control and NaSal lanes represent independent RT-PCR products obtained from CDNA first strand reactions derived from different mRNA preparations. Lanes indicating pUCTR-3 and RNA w/o RTase are positive and negative controls, respectively. The products were fractionated on $1.2 \%$ agarose gel, and stained with ethidium bromide $(0.5$ $\mu \mathrm{g} / \mathrm{ml})$.

stimulated gene named TSG-5 has also been identified and is currently under functional characterization by our group (Pires EG, Abrantes EF, Carvalho AF and Reis LFL, unpublished data).

It is important to state that DDRT-PCR is quite reproducible. By comparing the duplicate lanes in Figure 2A, one will observe a significant degree of similarity in the band pattern. Nevertheless, it should be pointed out that reproducibility is not a central issue in this methodology and ultimately only Northern blot or RT-PCR analysis will confirm the differential expression of a given gene.

Thus, we can conclude that, under optimal conditions, DDRT-PCR is in fact a powerful approach for the identification of genes whose expression is modulated by changing stimuli, culture conditions, or even different stages of pathology. We are currently applying the DDRT-PCR technique to compare and identify new genes that are expressed in normal gastric mucosa and gastric tumors. 


\section{Acknowledgments}

We thank Elisângela Monteiro and Anna Christina de Matos Salim, Laboratory of
Cancer Genetics, LICR, São Paulo, for providing all sequencing data. We also thank the members of the Laboratory of Inflammation for helpful discussion.

\section{References}

1. Liang P \& Pardee AB (1992). Differential display of eukaryotic messenger RNA by means of the polymerase chain reaction. Science, 257: 967-970.

2. Liang P, Averboukh L \& Pardee AB (1993). Distribution and cloning of eukaryotic mRNAs by means of differential display: refinements and optimization. Nucleic Acids Research, 21: 3269-3275.

3. Welsh J, Chada K, Dalal S, Cheng R, Ralph D \& McClelland M (1992). Arbitrarily primed PCR fingerprinting of RNA. Nucleic Acids Research, 20: 4965-4970.

4. Lee SW, Tomasetto C \& Sager R (1991). Positive selection of candidate tumor-suppressor genes by subtractive hybridization. Proceedings of the National Academy of Sciences, USA, 88: 2825-2829.

5. Velculescu V, Zhang L, Vogelstein B \& Kinzler K (1995). Serial analysis of gene expression. Science, 270: 484-487.

6. Hubank M \& Chatz D (1994). Identifying differences in mRNA expression by representational difference analysis of CDNA. Nucleic Acids Research, 22: 5640-5648.

7. DeRisi J , Penland L, Brown $P$, Bittner $M$, Meltzer $P$, Ray $M$, Chen $Y \&$ Trent J (1996). Use of a cDNA microarray to analyse gene expression patterns with a complementary DNA microarray. Nature Genetics, 14: 457-460.

8. Zhang L, Zhou W, Velculescu V, Kem S, Hruban R, Hamilton S, Vogelstein B \& Kinzler K (1997). Gene expression profiles in normal and cancer cells. Science, 276: 1268-1272.

9. Wan J S, Sharp SJ, Poirier GM-C, Wagaman PC, Chambers J , Pyati J, Hom Y-L, Galindo J E, Huvar A, Peterson PA, J ackson MR \& Erlander MG (1996). Cloning differentially expressed mRNAs. Nature Biotechnology, 14: 1685-1691.

10. Hess J , Laumen $\mathrm{H} \&$ Wirth $\mathrm{T}$ (1998). Application of differential CDNA screening techniques to the identification of unique gene expression in tumours and lymphocytes. Current Opinion in Immunology, 10: 125-130.

11. Vilcek J \& Sen GC (1996). IFNs and other cytokines. In: Fields BN, Knipe DM, Howley PM, Chanok RM, Melnick JL,
Monath TP, Roizman B \& Straus SE (Editors), Fields Virology. Lippincott-Raven, Philadelphia.

12. Pellegrini $S \&$ Schindler C (1993). Early events in signalling by interferons. Trends in Biochemical Sciences, 18: 338-342.

13. Sen GC \& Lengyel P (1992). The interferon system. J oumal of Biological Chemistry, 267: 5017-5020.

14. Williams BR (1991). Transcriptional regulation of interferon-stimulated genes. European J ournal of Biochemistry, 200: 111.

15. Miyamoto $M$, Fujita $T$, Kimura $Y$, Maruyama M, Harada H, Sudo Y, Miyata T \& Taniguchi T (1988). Regulated expression of a gene encoding a nuclear factor, IRF-1, that specifically binds to IFN-beta gene regulatory elements. Cell, 54: 903913.

16. Fujita T, Sakakibara J, Sudo $Y$, Miyamoto M, Kimura $Y \&$ \& Taniguchi T (1988). Evidence for a nuclear factor(s), IRF-1, mediating induction and silencing properties to human IFN-beta gene regulatory elements. EMBO J ournal, 7: 3397-3405.

17. Fujita T, Reis LFL, Watanabe N, Kimura Y, Taniguchi T \& VilcekJ (1989). Induction of the transcription factor IRF-1 and interferon-beta mRNAs by cytokines and activators of second-messenger pathways. Proceedings of the National Academy of Sciences, USA, 86: 9936-9940.

18. Reis LFL, Harada H, Wolchok JD, Taniguchi T \& Vilcek J (1992). Critical role of a common transcription factor, IRF-1, in the regulation of IFN-beta and IFN-inducible genes. EMBO J ournal, 11: 185193.

19. Rutherford $M N$, Kumar $A$, Nissim A, Chebath J \& Williams BR (1991). The murine 2-5A synthetase locus: three distinct transcripts from two linked genes. Nucleic Acids Research, 19: 1917-1924.

20. Lee SB, Melkova Z, Yan W, Williams BR, Hovanessian AG \& Esteban M (1993). The interferon-induced double-stranded RNAactivated human p68 protein kinase potently inhibits protein synthesis in cultured cells. Virology, 192: 380-385.

21. Meurs EF, Watanabe Y, Kadereit S, Bar- ber GN, Katze MG, Chong K, Williams BR \& Hovanessian AG (1992). Constitutive expression of human double-stranded RNA-activated p68 kinase in murine cells mediates phosphorylation of eukaryotic initiation factor 2 and partial resistance to encephalomyocarditis virus growth. J ournal of Virology, 66: 5804-5814.

22. Staeheli $P \&$ Haller $O$ (1987). Interferoninduced $M \times$ protein: a mediator of cellular resistance to influenza virus. Interferon, 8: 1-23.

23. Baeuerle PA \& Baltimore D (1996). NF$\kappa B$ : ten years after. Cell, 87: 13-20.

24. Baldwin J r AS (1996). The NF- $\kappa B$ and I $k B$ proteins: new discoveries and insights. Annual Review in Immunology, 14: 649683.

25. Beauparlant $P \&$ Hiscott J (1996). Biological and biochemical inhibitors of the NF$\kappa \mathrm{B} /$ Rel proteins and cytokine synthesis. Cytokine Growth Factor Reviews, 7: 175190.

26. Schwenger $P$, Bellosta $P$, Vietor I, Basilico C, Skolnik EY \& Vilcek J (1997). Sodium salicylate induces apoptosis via p38 mitogen-activated protein kinase but inhibits tumor necrosis factor-induced $\mathrm{C}-\mathrm{J}$ un $\mathrm{N}$ terminal kinase/stress-activated protein $\mathrm{ki}$ nase activation. Proceedings of the $\mathrm{Na}$ tional Academy of Sciences, USA, 94: 2869-2873.

27. Schwenger $P$, Alpert $D$, Skolnik EY \& Vilcek J (1998). Activation of p38 mitogen-activated protein kinase by sodium salicylate leads to inhibition of tumor necrosis factor-induced IкBalpha phosphorylation and degradation. Molecular and Cellular Biology, 18: 78-84.

28. Schwenger P, Skolnik EY \& Vilcek J (1996). Inhibition of tumor necrosis factor-induced p42/p44 mitogen-activated protein kinase by sodium salicylate. J ournal of Biological Chemistry, 271: 80898094.

29. Camargo MM, Almeida IC, Pereira ME, Ferguson MA, Travassos LR \& Gazzinelli RT (1997). Glycosylphosphatidylinositolanchored mucin-like glycoproteins isolated from Trypanosoma cruzi trypomastigotes initiate the synthesis of proinflam- 
matory cytokines by macrophages. J ournal of Immunology, 158: 5890-5901.

30. Camargo MM, Andrade AC, Almeida IC, Travassos LR \& Gazzinelli RT (1997). Glycoconjugates isolated from Trypanosoma cruzi but not from Leishmania species membranes trigger nitric oxide synthesis as well as microbicidal activity in IFNgamma-primed macrophages. J ournal of Immunology, 159: 6131-6139.

31. Gazzinelli RT, Camargo MM, Almeida IC, Morita YS, Giraldo M, Acosta-Serrano A, Hieny $S$, Englund PT, Ferguson MA, Travassos LR \& Sher A (1997). Identification and characterization of protozoan products that trigger the synthesis of IL12 by inflammatory macrophages. Chemical Immunology, 68: 136-152.

32. Reis LFL, Ruffner $H$, Stark $G$, Aguet $M \&$ Weissmann C (1994). Mice devoid of interferon regulatory factor 1 (IRF-1) show normal expression of type I interferon genes. EMBO J ournal, 13: 4798-4806.

33. Chomczynski $P \&$ Sacchi N (1987). Single step method of RNA isolation by acid guanidinium thiocyanate-phenol-chloroform extraction. Analytical Biochemistry, 162: 156-159.

34. Durbin J E, Hackenmiller MC, Simon MC \& Levy DE (1996). Targeted disruption of the mouse STAT1 gene results in compromised innate immunity to viral disease. Cell, 84: 443-450.

35. Savage $P$, Horton $V$, Moore J, Owens $M$, Witt P \& Gore ME (1996). A phase I clinical trial of imiquimod, an oral interferon inducer, administered daily. British J ournal of Cancer, 74: 1482-1486.

36. Bottrel RLA, Yang Y-L, Levy DE, Tomai M $\&$ Reis LFL (1999). The immune response modifier imiquimod requires STAT-1 for induction of interferon, interferon-stimu- lated genes, and interleukin-6. Antimicrobiol Agents and Chemotherapy (in press).

37. Altschul SF, Gish W, Miller W, Myers EW \& Lipman DJ (1990). Basic local alignment search tool. J ournal of Biological Chemistry, 215: 403-410.

38. Sambrook J, Fritisch EF \& Maniatis T (1989). Molecular Cloning. A Laboratory Manual. Cold Spring Harbor Laboratory Press, Cold Spring Harbor.

39. Church GM \& Gilbert W (1984). Genomic sequencing. Proceedings of the National Academy of Sciences, USA, 81: 19911995.

40. Silva AM, Bottrel RL \& Reis LFL (1999). Identification and partial characterization of FRAG-6, a new interferon-stimulated gene that is induced in an IRF-1-independent manner. Cytokine (in press). 